\title{
Investigating the Effect of Advertising on the Perception of the Target Audience with the CAPI Technique
}

\author{
Reklamın Hedef Kitle Algısına Etkisinin CAPI Tekniği ile Araştırılması
}

\author{
H. Serhat ÇERÇi \\ Lect., Dr., Selcuk University \\ hserhatcerci@gmail.com \\ https://orcid.org/0000-0002-5580-2057
}

$\begin{array}{ll}\text { Received } & : 16.12 .2021 \\ \text { Revised } & : 26.12 .2021 \\ \text { Accepted } & : 29.12 .2021 \\ \text { Type of Article } & : \text { Research }\end{array}$

A. Selçuk KÖYLÜOĞLU

Assist., Prof., Selcuk University

selcuk641@gmail.com

https://orcid.org/0000-0003-0359-1443

\section{ABSTRACT}

Keywords:

Advertisement

CAPI Technique,

Target Audience

Perception

By creating brand awareness and marketing strategies with effective advertising practices, the effect of advertising on consumer perception can be understood. The aim of the study, which is built on this understanding, is to examine the advertisement film used in the marketing and promotion activities of a hotel business operating in the tourism sector with the CAPI technique. From this point of view, the research was implemented in three big cities, namely Istanbul, Izmir and Ankara. As a result of the field research, 150 meaningful data could be obtained due to the limitations such as the face-to-face application and the timeconsuming nature of CAPI and narrowing of the criteria for those who will participate in the survey under the effect of the pandemic conditions. The data were subjected to the SPSS 20 program. As a result of the statistical analysis, it has been determined that the advertisement appeals to consumer emotions.

Anahtar Kelimeler:

Reklam,

CAPI Tekniği,

Hedef Kitle Algisl
Etkili reklam uygulamaları ile marka bilinirliği ve pazarlama stratejileri oluşturularak, reklamın tüketici algısı üzerindeki etkisi anlaşılabilir. Bu anlayış üzerine inşa edilen çalışmanın amacı, turizm sektöründe faaliyet gösteren bir otel işletmesinin pazarlama ve tanıtım faaliyetlerinde kullandı̆̆ reklam filmini CAPI tekniği ile incelemektir. Bu noktadan hareketle araştırma İstanbul, İzmir ve Ankara olmak üzere üç büyük şehirde gerçekleştirilmiştir. Alan araştırması sonucunda, CAPI'nin yüz yüze uygulanması ve zaman alıcı olması gibi sinırlılıklar ve ankete katılacak olanlar için pandemic koşıllarından dolayı kriterlerin daraltılması nedeniyle 150 anlaml veri elde edilebilmiştir. Veriler SPSS 20 programına tabi tutuldu. Istatistiksel analiz sonucunda reklamın tüketici duygularına hitap ettiği tespit edilmiştir. 


\section{INTRODUCTION}

In a brutal competitive environment, the success of the firm largely depends on how professionally the marketing communication elements are used. In this respect, advertising has a very critical role in achieving the stated goal. This is the productive part of the issue. However, the consumer side should definitely be emphasized, because all these and similar efforts by the producers are to convince the consumers. In order for consumers to realize a purchase behavior, they must be aware of the product. Therefore, ensuring that the consumer has this information during the purchasing process will accelerate the process in question and ensure the realization of the purchasing behavior (Tayfur, 2010). In this respect, it can be said that advertising is a powerful promotional weapon used in the field of marketing (Steel, 2000).

In the field of tourism, marketing communication tools have critical importance in determining the marketing strategy and consumer needs and demands. In addition, sensitivity to commercial advertisements (Koenigs \& Tranel, 2007) affects consumers' purchasing decisions (Bargh, 2002; Shrum et al, 2012). This situation is of greater importance for service businesses, and hotels have a serious influence among service businesses as a matter of fact. Service businesses need more image factors than businesses in the manufacturing sector. The main reason for this is that the companies in the service sector have relatively little opportunity to benefit from the visuals of their products in order to differentiate themselves from their competitors, increase their popularity and be preferred. The advertising factor comes to the fore in meeting this argument that service businesses are lacking. However, one of the two main difficulties experienced at this point is the cost of advertising expenditures; The other is that the rate of companies creating effective advertisements is statistically low. The shortcomings of classical research methods due to their cult characteristics, at the point of revealing the effectiveness of advertising, the level of interest of the advertisements in the target consumer group and whether they can establish the right communication with them, have led to the emergence of new techniques thanks to the radical developments in technology. The CAPI technique, on the other hand, emerged as a technique that eventually embodied these evolutions. With the development of computer-assisted interview systems, the computerized form of face-to-face interviews is called computer-assisted personal interviews (CAPI). When evaluated from a general perspective, it is a system that enables the compilation of data by using computer-assisted, registered question forms and conducting the survey face-to-face via computer (Ventura, 2003).

This study is expected to contribute to the literature in terms of both researching the effectiveness of advertising in hotel businesses and using a different technique in the field of marketing such as CAPI. Because in the literature, the number of studies conducted to investigate the advertisement with the CAPI technique is limited. The study is also important in terms of filling this gap. In this context, in the study, the commercial ad film used in the marketing and promotion activities of a hotel business operating in the tourism sector was examined with the help of the CAPI technique. The research was carried out in three big cities, namely Istanbul, Izmir and Ankara. As a result of the field research, 150 meaningful data could be obtained due to the limitations such as the face-to-face application of CAPI and the time consuming and narrowing of the scope of the criteria sought for those who will participate in the survey because of pandemic conditions. The data were subjected to the SPSS 20 program. As a result of the statistical analysis, it has been determined that the advertisement appeals to consumer emotions. In future studies, conducting the research with more samples and using different techniques and analyzes, both qualitative and quantitative, will enable to reach different results.

The study continues with a literature review after the introduction. The third part is the material and method. In this section, the purpose, importance, universe, and sample of the research are included. In the following section, the findings obtained through statistical analysis are given. In the fifth chapter, the conclusion and discussion, there are both general evaluations, limitations and administrative practices. (Düzenlendi)Orijinali geri yükle

\section{LITERATURE REVIEW}

Researchers have dealt with advertising in many dimensions and included various definitions. According to Classer (1972), advertising is the actions taken to present a message about a good or service to the market units verbally or visually. McLuhan (2005) claims that advertising is 20th century cave art. Cohen (2015) defines it as the promotion of the advertiser in mass media in a way that provides credible communication to achieve its goals (Richards and Curran, 2002). Jefkins (2000) says that advertising is the tool that makes known what we have to buy or sell. Foster (1997) stated that "Advertising is not a science, it is a work of persuasion and persuasion is an art". Tikveş (2005) describes it as a mass and paid sales effort conveyed by the marketer to the units embodying a particular market. 
Advertising in hospitality business is the name given to a collection of different marketing techniques used to promote a hotel and its services. In general, the main purpose behind advertising for hospitality businesses is to portray the business in a positive way and connect with the target audience in a way that makes them more likely to become a paying customer. Advertising is often persuasive in nature, tends to target an audience rather than individuals, and aims to deliver improvements in business results in the short term or long term. This is why advertisements are one of the most important ways for hospitality businesses to generate interest and promote their unique offers. Advertising is also one of the elements of the promotion mix (Kotler et al., 2003). Advertising in the hospitality business is the promotion of an accommodation business and its services to consumers and buyers in the target market through mass media for a fee (Bltyhe, 2001)

Since the main purpose behind the advertising strategies of accommodation businesses is to create more business, it is possible for many businesses to follow their branding goals, create customer awareness, communicate their values, and emphasize their qualities, and ultimately communicate with the target audience and create sympathy and customer headlines through advertising activities. Advertising is one of the main ways hospitality businesses stand out from their competitors and communicate their unique selling points. A successful advertisement will also encourage customer loyalty. Hospitality businesses and destination advertising play an important role as a source of communication for both passengers and destination managers. Business managers often rely on their advertisements to attract tourists who tend to plan their itineraries around such advertisements. Destination advertising has the potential to successfully increase tourist demand (Byun \& Jang, 2015).

With the development of computer-assisted interview systems, the computerized form of face-to-face interviews is called computer-assisted personal interviews (CAPI). This system enables the compilation of data by making face-to-face questionnaires via computer using supported questionnaires saved on the computer. It refers to the collection of survey data by a computer user to administer the survey and a face-to-face interviewer who computerizes the answers. This interview technique is a relatively new development in survey research, made possible by the personal computer revolution. In other words, it is a blended and advanced version of the classical survey method with technology. This method has some advantages over the traditional survey method. Routing problems in the survey are eliminated. Interviewers cannot miss questions or ask the wrong questions. Questions can be customized correctly. Mathematical calculations can be made within the program. The program checks for unacceptable or inconsistent responses and errors caused by different data entry are eliminated. Moreover, images can be included in the survey in a rich and colorful way, allowing videos to be added and watched. CAPI practitioners can control whether the participants watch the visuals and prevent memorized answers. Today's popular techniques such as Computer-Assisted Telephone Interviewing (CATI) and Computer-Assisted Personnel Interviewing (CAPI) will be used more frequently as their superior aspects are adopted compared to traditional questionnaire preparation (Ventura, 2003).

Ahmed and Ashfaq (2013) revealed that a creative and well-executed advertisement always has a great influence on consumers' purchasing tendencies or purchasing behavior. According to Fatima and Lodhi (2015), advertisements are very effective in creating awareness among people, but fail to have strong perceptions in the consumer's mind. Rai (2013) built his work on two main objectives, namely the effect of advertising on purchasing behavior and consumer attitude formation. He concluded that advertisements affect purchasing behavior and consumer attitude not only in India but all over the world.

There are many studies in the literature to measure the effects of advertising in the tourism sector. Jones (1995) analyzed hundreds of ads along with advertisers' sales charts and concluded that the strongest ad campaigns could triple sales, while the weakest could contribute to a more than 50 percent drop in sales. Making a few observations about internal momentum, Jones (1995) concluded that as a brand's market share grows, its advertising expenditure tends to increase at a decreasing rate, and as the brand grows, its reputation with consumers increases. Therefore, brand awareness reduces the advertising and promotion costs of businesses (Uzkurt and Bölükbaş1, 2008).

\section{MATERIALS AND METHOD}

As a research methodology, this application has been compiled under several headings in this section. In the first stage, a general introduction of the company included in the research was made. Afterwards, why the subject was researched and what was aimed with the results obtained at the end of the research were discussed in the aim of the research. Contributions to the theory or the field of practice through research are mentioned in the importance part of the research. In the method part of the research, answers were sought to questions such as how the collected data were obtained, what is the scope and universe of the research, what kind of problems this information solved 
and how it was used, which methods and techniques were used in this process. The resulting findings were also analyzed and interpreted.

\subsection{Introduction of the Company Included in the Research}

It is a luxury hotel with a total of 125 deluxe rooms, including Royal Suites, and 103 standard deluxe and 14 junior suites, 6 queen and 8 king suites in the other block, affiliated with a chain of 5 -star group hotels operating in the tourism sector under Merit Royal brand name. İt is established in two blocks operating on the Mediterranean coast in North Cyprus, it has 16 king suites, 32 queen suites, 4 junior suites, 71 standard deluxe rooms,

\subsection{Research Problematic}

Marketing research is critical in determining the marketing strategy and consumer needs and demands in the field of tourism. People are sensitive to commercial advertisements (Koenigs \& Tranel, 2007), and the main purpose of all types of marketing is to influence consumers' purchasing decisions (Bargh, 2002; Shrum et al, 2012). In line with this information, answers to the following questions are sought:

How do consumers react to hotel advertising?

What do consumers pay attention to in hotel advertisements?

What results does the hotel advertisement show with CAPI, which is considered a classical quantitative research method on the basis of consumer reactions?

\subsection{Purpose and Importance of the Research}

This study is expected to contribute to the literature in terms of both researching the effectiveness of advertising in hotel businesses and using a different technique in the field of marketing, such as CAPI. Because in the literature, the number of studies conducted to investigate the advertisement with the CAPI technique is limited. This study is also important to fill this gap. In this context, in the study the commercial film used in the marketing and promotion activities of a hotel business operating in the tourism sector was examined with the help of the CAPI technique.

\subsection{Research Method}

In the research, CAPI (Computer Assisted Personnel Interviewing) method, which is a computer-assisted face-toface interview technique, was used as a non-experimental method. With the development of computer-assisted interview systems, the computerized form of face-to-face interviews is called computer-assisted personal interviews (CAPI). It is a system that enables the data to be compiled by making face-to-face surveys via computer using supported questionnaires stored on the computer. It refers to the collection of survey data by a computer user to administer the survey and a face-to-face interviewer who computerizes the answers. This interview technique is a relatively new development in survey research, made possible by the personal computer revolution. This method has some advantages over the traditional survey method. Routing problems in the survey are eliminated. Interviewers cannot miss questions or ask the wrong questions. Questions can be customized correctly. Mathematical calculations can be made within the program.

The program checks for unacceptable or inconsistent responses and errors caused by different data entry are eliminated. Moreover, images can be included in the survey in a rich and colorful way, allowing videos to be added and watched. CAPI practitioners can control whether the participants watch the visuals and prevent memorized answers. Accordingly, the CAPI research was conducted in three big cities, namely Istanbul, Izmir and Ankara. As a result of the field research, 150 meaningful data could be reached due to the limitations such as the face-to-face application of CAPI and the time consuming and narrowing of the scope of the criteria sought for the people who will participate in the survey, completely due to the effect of the pandemic conditions. These data were analyzed with the SPSS 20 program.

\section{RESULTS}

In this section a quantitative research technique, computer-assisted personal interview method and the analysis and numerical results of its results were used in order to make general evaluations for hotels in Cyprus, for brand awareness, and evaluations for commercials. Since the Merit Royal Hotel, whose advertising effectiveness is being measured, is a 5-star hotel in Cyprus, the pre-criteria sought for the participants for the CAPI study were determined as follows:

-Those who travel to Cyprus and prefer 5-star hotels to stay 
-Those who decide on their own choice of hotel

- Those who watch TV at least once a week

The demographic characteristics of the participants in this research, which aims to measure the effectiveness of Merit Royal Hotel's commercials on the basis of certain topics, are as follows:

Table 1. Demographic Characteristics of the Participants

\begin{tabular}{|c|c|}
\hline Demographics & Percentage \\
\hline \multicolumn{2}{|l|}{ Gender } \\
\hline Female & 50 \\
\hline Male & 50 \\
\hline Total & 100 \\
\hline \multicolumn{2}{|l|}{ Age } \\
\hline 20-35 years old & 50 \\
\hline $35-50$ years old & 50 \\
\hline Total & 100 \\
\hline \multicolumn{2}{|l|}{ Marital status } \\
\hline Single & 65 \\
\hline married & 35 \\
\hline Total & 100 \\
\hline \multicolumn{2}{|l|}{ child ownership } \\
\hline yes & 36 \\
\hline no & 64 \\
\hline Total & 100 \\
\hline \multicolumn{2}{|l|}{ Province } \\
\hline Ankara & 20 \\
\hline Istanbul & 60 \\
\hline Izmir & 20 \\
\hline Total & 100 \\
\hline \multicolumn{2}{|l|}{ Socioeconomic status } \\
\hline EU & 64 \\
\hline $\mathrm{C} 1$ & 36 \\
\hline Total & 100 \\
\hline \multicolumn{2}{|c|}{ Frequency of going to Cyprus } \\
\hline 1 in a year & 40 \\
\hline 1 in two years & 34 \\
\hline once a month & 7 \\
\hline 1 in 4-6 months & 7 \\
\hline 1 in $2-3$ months & 5 \\
\hline every 2 weeks & 5 \\
\hline once a week & 2 \\
\hline Total & 100 \\
\hline \multicolumn{2}{|l|}{ TV viewing frequency } \\
\hline Every day & 63 \\
\hline Every other day & 11 \\
\hline Twice a week or less & 13 \\
\hline Once a week & 13 \\
\hline Total & 100 \\
\hline
\end{tabular}

According to this table, 75 people corresponding to $50 \%$ of the 150 participants in the study were women; It is seen that 75 people, corresponding to the other $50 \%$, are men. When the distribution of the participants in the 
study by age is examined, it is seen that $50 \%$ of them are in the age range of $20-35$, and $50 \%$ of them are in the age range of 35-50. According to these data, the average age is 35 years. It is seen in the table that $65 \%$ of the participants in the study are single and $35 \%$ are married. While $36 \%$ of the participants have children, it is seen that $64 \%$ do not have children. $60 \%$ of the participants are in Istanbul, $20 \%$ in İzmir and $20 \%$ in Ankara. According to the data in this table, where occupational groups are coded according to socioeconomic status, $64 \%$ of the participants have $\mathrm{AB}$ group occupations and $36 \%$ have $\mathrm{C}$ group occupations. When the frequency of going to Cyprus is examined, $40 \%$ of the participants once a year, $34 \%$ once every 2 years, $7 \%$ once a month, $7 \%$ once in 4-6 months, 5\% every 2-3 months. It is seen that once a month, 5\% of them travel to Cyprus once every 2 weeks and $2 \%$ of them once a week. $63 \%$ of the sample group participating in the study watch television every day, $11 \%$ watch television every other day, $13 \%$ watch television twice a week or less, and $13 \%$ watch television once a week.

\subsection{Evaluations for Brand Awareness}

The aim of this part of the research is to reveal the extent to which Merit Royal Hotel, differs as a brand among the 5-star hotels operating in Cyprus before the commercial film is watched. First of all, questions were asked to the participants in order to obtain general data on the recall of the hotels. "Can you tell me the first 5 hotels that come to your mind when you say Cyprus?" When the answers of the participants to the question were examined, it was determined that the Merit Royal Brand was in the first place in this list with a composite average of $40 \%$ first and secondary utterances. It is followed by Cratos Premium Hotel with an average of $29 \%$, Elexus Hotel with an average of $23 \%$, Limak Deluxe Hotel with an average of $20 \%$ and Noah's Ark Delux Hotel with an average of $9 \%$. The rate of mentioning the name Merit Royal as the first brand was determined as $31 \%$.

Table 2. Distribution of Brands Remembered Without Assistance

\begin{tabular}{|l|c|}
\hline Brand name & Percentage \\
\hline Merit Royal Hotel & 40 \\
\hline Cratos Premium Hotel & 29 \\
\hline Elexus Hotel & 23 \\
\hline Limak Deluxe Hotel & 20 \\
\hline Nuh'un Gemisi Deluxe Hotel & 9 \\
\hline
\end{tabular}

When the brands were asked to be remembered by using certain reminders for other brands that could not be remembered unaided, the Merit Royal brand was remembered by $85 \%$ and ranked first. Other assisted brands and their recall levels are given in the table below. During the assisted reminding, the participants were asked whether they remembered the commercials of these hotel brands. According to the answers received, the rate of remembering the commercials of the hotel brands and the recall rate of the brand's name are given in the table below.

Tablo 3. Distribution of Brands and Ads Recalled with Assistance

\begin{tabular}{|c|c|c|}
\hline Brand & Recalling Percentage & Ad Recalling Percentage \\
\hline Merit Royal Hotel & 85 & 27 \\
\hline Limak Deluxe Hotel & 70 & 8 \\
\hline Elexus Hotel & 64 & 9 \\
\hline Cratos Premium Hotel & 64 & 13 \\
\hline Golden Bay Beach Hotel & 58 & 8 \\
\hline Kaya Palazzo Resort & 55 & 7 \\
\hline
\end{tabular}

As can be seen in this table, with an assisting reminder both the brand name and the commercial of Merit Royal Hotel were remembered at a higher rate than the others. The rate of users who stated that they remembered the commercial is $27 \%$. 


\subsection{Evaluations on Accommodation Habits}

When the respondents were asked for what purpose they usually stay in hotels in Cyprus, $79 \%$ of them stated that they stayed for holiday purposes and $21 \%$ of them stated that they stayed for business purposes.

Table 4. Reasons for Participants to Accommodate in Cyprus

\begin{tabular}{|c|c|}
\hline Reason & Percentage \\
\hline Holiday & 79 \\
\hline Business & 21 \\
\hline Total & $\mathbf{1 0 0}$ \\
\hline
\end{tabular}

In order to determine the hotels they prefer to accommodate in when they travel to Cyprus, the participants were asked to say the name of the Hotel they stay most frequently in Cyprus and the names of the other hotels they stayed in Cyprus. Accordingly, the rates of preference among the most frequently and other hotels are as follows:

Table 5. Distribution of Hotels Preferred for Accommodation in Cyprus

\begin{tabular}{|c|c|c|c|}
\hline Brand & $\begin{array}{c}\text { Most Frequent } \\
\text { Accommodation Rate }\end{array}$ & $\begin{array}{c}\text { Secondary } \\
\text { Accommodation rate }\end{array}$ & $\begin{array}{c}\text { Total Accommodation } \\
\text { Rate }\end{array}$ \\
\hline Nuh'un gemisi Deluxe Hotel & $\% 6$ & $\% 50$ & $\% 56$ \\
\hline Merit Royal Hotel & $\% 30$ & $\% 11$ & $\% 41$ \\
\hline Cratos Premium Hotel & $\% 19$ & $\% 17$ & $\% 36$ \\
\hline Elexus Hotel & $\% 18$ & $\% 9$ & $\% 27$ \\
\hline Limak Deluxe Hotel & $\% 12$ & $\% 11$ & $\% 23$ \\
\hline
\end{tabular}

According to the data in the table, among the brands that the participants in the study preferred to stay in their past travels, the brand with the highest rate of total visitors was Noah's ship Deluxe Hotel with $56 \%$. While Merit Royal Hotel is in the second place with a total accommodation rate of $41 \%$, Cratos Premium Hotel is in the 3 rd place with $36 \%$. The rate of participants staying at Elexus Hotel is $27 \%$. Limak Delux Hotel, on the other hand, ranks fifth with a total accommodation rate of $23 \%$. Merit Royal Hotel ranks first with $30 \%$ in the most frequent accommodation rate.

When users were asked to rate their level of satisfaction with the hotel they stayed at over 10 points, $48 \%$ of them expressed an opinion in the range of $10-9$ points, and $51 \%$ in the range of $8-7$ points.

Table 6. Satisfaction with the Most Frequently Stayed Hotel

\begin{tabular}{|c|c|}
\hline Satisfaction Level & Percentage \\
\hline I am very satisfied (10-9 points) & 48 \\
\hline I am satisfied (8-7 points) & 51 \\
\hline I am neither satisfied nor not (6-5 points) & 1 \\
\hline I am not satisfied (4-3 points) & 0 \\
\hline Not at all satisfied (2-1 points) & $\mathbf{1 0 0}$ \\
\hline Total & \\
\hline
\end{tabular}

According to the table, the satisfaction level of the participants from the hotel they stay most frequently in Cyprus is quite high. The satisfaction level of the participants who stated that they stayed at Merit Royal Hotel was determined as 8.8 out of 10 . The average satisfaction level of other Hotel customers was determined as 8.5 out of 10.

Table 7. Comparative Average Hotel Satisfaction Scores

\begin{tabular}{|c|c|}
\hline Customer Type & Average satisfaction out of 10 points \\
\hline Merit Royal Customers & 8.8 \\
\hline Other Hotel Customers & 8.5 \\
\hline
\end{tabular}


According to these findings, the satisfaction average of the participants who stayed at the Merit Royal Hotel is slightly higher than the others.

\subsection{Evaluations for the Advertising Film}

The ad appreciation level grouped by demographic characteristics and the average appreciation scores are as follows:

Table 8. Level of Appreciation by Demographic Groups

\begin{tabular}{|c|c|}
\hline By City & Average Score (out of 10) \\
\hline Istanbul & 8.4 \\
\hline Ankara & 7.1 \\
\hline Izmir & 8.2 \\
\hline By Gender & Score \\
\hline Female & 8.3 \\
\hline Male & 7.9 \\
\hline By Age Group & Score \\
\hline $20-35$ & 7,8 \\
\hline $36-55$ & 8,3 \\
\hline By Marital Status & Score \\
\hline married & 8,1 \\
\hline Single & 8,1 \\
\hline According to the Status of Being a Hotel Customer & Score \\
\hline Merit Royal Customers & 8.5 \\
\hline Other Hotel Customers & 7.8 \\
\hline
\end{tabular}

According to this table, the participants in Istanbul and Izmir liked the commercial more than the participants in Ankara. On the basis of gender, the average score of appreciation of women is higher than that of men; female participants liked the ad more. Looking at the age groups, it is seen that the participants between the ages of 3655 liked the advertisement more than the other participants.

Table 9. The Success of the Advertisement to Remind the Brand

\begin{tabular}{|c|c|}
\hline Level of Ad Success & Percentage \\
\hline A very successful commercial. & 31 \\
\hline A very successful commercial. & 57 \\
\hline Not a very successful commercial. & 5 \\
\hline This movie could have been for any hotel commercial & 7 \\
\hline Total & $\mathbf{1 0 0}$ \\
\hline
\end{tabular}

The total ratio of the answers to "a very successful commercial film" and "a highly successful commercial film" is $88 \%$; This high level reveals that the advertisement is successful in reminding the brand. However, the $12 \%$ of the participants who did not find the advertisement successful stated the reasons for this as being ordinary, clichéd, not descriptive, and the lack of Merit Royal emphasis.

Table 10. Distribution of Finding the Advertisement Different

\begin{tabular}{|c|c|c|c|c|c|c|c|c|c|c|c|}
\hline & General & İstanbul & Ankara & İzmir & Female & Male & $\mathbf{2 0 - 3 5}$ & $\mathbf{3 6 - 5 5}$ & $\mathbf{A}$ & $\mathbf{B}$ & $\mathbf{C 1}$ \\
\cline { 2 - 26 } Base & 150 & 90 & 30 & 30 & 75 & 75 & 75 & 75 & 43 & 53 & 54 \\
\hline TB \% & 20 & 28 & 7 & 10 & 21 & 18 & 16 & 24 & 19 & 17 & 24 \\
\hline T2B \% & 74 & 79 & 63 & 71 & 69 & 79 & 63 & $85(\mathrm{f})$ & 70 & 74 & 78 \\
\hline
\end{tabular}


A similar situation emerged according to gender. Accordingly, the level of finding the advertisement different in men is higher than in women. This situation, which continued according to age groups, resulted in the 36-55 age group finding the advertisement significantly different from the 20-35 age group.

The evaluations regarding the power of the advertisement to direct to the brand, which is another important element of the advertisement, are as follows:

Tablo 11. The Power of Advertising to Direct The Brand

\begin{tabular}{|c|c|}
\hline Desire of Accommodation at Merit Royal Hotel after Ad & Percentage \\
\hline I would definitely like to stay & 42 \\
\hline I want to stay & 49 \\
\hline I'm undecided & 5 \\
\hline I don't want to stay & 2 \\
\hline I definitely don't want to stay & 2 \\
\hline Total & $\mathbf{1 0 0}$ \\
\hline
\end{tabular}

According to this table, which presents the findings about the extent to which users want to stay at Merit Royal Hotel after watching the commercial, $91 \%$ of the participants stated that they would like to stay. This high rate reveals that the advertisement is quite strong in directing the brand.

Considering the distribution of evaluations for the advertisement, significant differences were found between Ankara and Istanbul participants. Throughout the table, it is seen that Merit Royal customers approach the advertisement more positively than the customers staying in other hotels. Relevant data are detailed in the table below.

Table 12. Distribution of Evaluations for Advertising

\begin{tabular}{|c|c|c|c|c|c|c|c|c|c|c|c|c|c|}
\hline \multirow{2}{*}{\multicolumn{2}{|c|}{ Base }} & General & İstanbul & Ankara & İzmir & Female & Male & $\begin{array}{l}20- \\
35\end{array}$ & $\begin{array}{l}36- \\
55\end{array}$ & Married & Single & $\begin{array}{c}\text { Merit } \\
\text { Customer }\end{array}$ & $\begin{array}{l}\text { Other } \\
\text { Customer }\end{array}$ \\
\hline & & 150 & 90 & 30 & 30 & 75 & 75 & 75 & 75 & 53 & 97 & 53 & 55 \\
\hline \multirow{2}{*}{$\begin{array}{c}\text { It is an advertisement that } \\
\text { appeals to the upper } \\
\text { segment. }\end{array}$} & $\begin{array}{l}\text { T4B } \\
(\%)\end{array}$ & 92 & 92 & 80 & 87 & 89 & 93 & 87 & 96 & 92 & 91 & 92 & 91 \\
\hline & $\begin{array}{l}\text { Avr } \\
/ 10)\end{array}$ & 8.7 & 8.8 & 8.2 & 8.8 & 8.6 & 8.8 & 8.5 & 8.9 & 8.9 & 8.6 & 8.9 & 8.6 \\
\hline \multirow{2}{*}{$\begin{array}{l}\text { It's an exciting ad. } \\
\text { It is an ad that evokes a } \\
\text { sense of happiness. }\end{array}$} & $\begin{array}{l}\text { T4B } \\
(\%)\end{array}$ & 88 & 87 & 80 & 100 & 85 & 91 & 82 & 95 & 94 & 85 & 60 & 61 \\
\hline & $\begin{array}{l}\text { Avr } \\
(/ 10)\end{array}$ & 7.8 & 7.9 & 7.3 & 8.0 & 7.8 & 7.8 & 7.3 & 8.3 & 7.9 & 7.7 & 8.0 & 7.7 \\
\hline \multirow[t]{2}{*}{$\begin{array}{l}\text { It's an attention-grabbing ad. } \\
\text { It's a comforting ad. }\end{array}$} & $\begin{array}{l}\text { T4B } \\
(\%)\end{array}$ & 88 & 87 & 80 & 100 & 85 & 91 & 82 & 95 & 94 & 85 & 60 & 61 \\
\hline & $\begin{array}{l}\text { Avr } \\
(/ 10)\end{array}$ & 7.8 & 7.9 & 7.3 & 8.0 & 7.8 & 7.8 & 7.3 & 8.3 & 7.9 & 7.7 & 8.0 & 7.7 \\
\hline \multirow{2}{*}{$\begin{array}{l}\text { It's a friendly ad. } \\
\text { It is an exaggerated and } \\
\text { meaningless advertisement. }\end{array}$} & $\begin{array}{l}\text { T4B } \\
(\%)\end{array}$ & 87 & 88 & 77 & 93 & 85 & 88 & 80 & 93 & 89 & 86 & 60 & 53 \\
\hline & $\begin{array}{l}\text { Avr } \\
(/ 10)\end{array}$ & 8.0 & 8.2 & 7.2 & 8.2 & 8.1 & 7.9 & 7.7. & 8.3 & 8.0 & 8.0 & 8.2 & 7.9 \\
\hline \multirow[t]{2}{*}{ It's a boring ad } & $\begin{array}{l}\text { T4B } \\
(\%)\end{array}$ & 74 & 80 & 57 & 71 & 71 & 76 & 66 & 81 & 74 & 73 & 79 & 70 \\
\hline & $\begin{array}{l}\text { Avr } \\
(/ 10)\end{array}$ & 7.4 & 7.9 & 6.4 & 7.1 & 7.5 & 7.4 & 7.1 & 7.8 & 7.4 & 7.5 & 7.7 & 7.2 \\
\hline \multirow[t]{2}{*}{ It's a stressful ad. } & $\begin{array}{l}\text { T4B } \\
(\%)\end{array}$ & 65 & 72 & 60 & 48 & 73 & 57 & 61 & 69 & 53 & 71 & 69 & 62 \\
\hline & $\begin{array}{l}\text { Avr } \\
/ 10)\end{array}$ & 7.2 & 7.7 & 6.5 & 6.5 & 7.6 & 6.9 & 6.9 & 7.5 & 6.9 & 7.4 & 7.5 & 7.0 \\
\hline
\end{tabular}




\begin{tabular}{|c|c|c|c|c|c|c|c|c|c|c|c|c|c|}
\hline \multirow{2}{*}{\multicolumn{2}{|c|}{ Base }} & General & İstanbul & Ankara & İzmir & Female & Male & $\begin{array}{l}20- \\
35\end{array}$ & $\begin{array}{l}36- \\
55\end{array}$ & Married & Single & $\begin{array}{c}\text { Merit } \\
\text { Customer }\end{array}$ & $\begin{array}{c}\text { Other } \\
\text { Customer }\end{array}$ \\
\hline & & 150 & 90 & 30 & 30 & 75 & 75 & 75 & 75 & 53 & 97 & 53 & 55 \\
\hline \multirow{2}{*}{$\begin{array}{l}\text { It's an annoying ad. } \\
\text { It is an advertisement that } \\
\text { appeals to the upper } \\
\text { segment. }\end{array}$} & $\begin{array}{l}\text { T4B } \\
(\%)\end{array}$ & 20 & 27 & 17 & 3 & 23 & 17 & 25 & 15 & 13 & 23 & 26 & 16 \\
\hline & $\begin{array}{c}\text { Avr } \\
(/ 10)\end{array}$ & 4.0 & 4.3 & 3.8 & 3.5 & 4.2 & 3.9 & 4.5 & 3.6 & 3.9 & 4.1 & 4.5 & 3.7 \\
\hline \multirow[t]{2}{*}{ It's an exciting ad. } & $\begin{array}{l}\text { T4B } \\
(\%)\end{array}$ & 13 & 18 & 7 & 3 & 11 & 14 & 16 & 9 & 4 & 17 & 18 & 9 \\
\hline & $\begin{array}{l}\text { Avr } \\
(/ 10)\end{array}$ & 3.3 & 3.5 & 3.1 & 3.1 & 3.1 & 3.5 & 3.5 & 3.1 & 2.9 & 3.6 & 3.8 & 3.0 \\
\hline \multirow{2}{*}{$\begin{array}{c}\text { It is an ad that evokes a } \\
\text { sense of happiness. } \\
\text { It's an attention-grabbing ad. }\end{array}$} & $\begin{array}{l}\text { T4B } \\
(\%)\end{array}$ & 12 & 18 & 7 & - & 11 & 13 & 13 & 11 & 8 & 14 & 15 & 10 \\
\hline & $\begin{array}{l}\text { Avr } \\
(/ 10)\end{array}$ & 3.2 & 3.5 & 3.1 & 2.7 & 3.2 & 3.3 & 3.5 & 3.0 & 3.0 & 3.4 & 3.6 & 3.0 \\
\hline \multirow[t]{2}{*}{ It's a comforting ad. } & $\begin{array}{l}\text { T4B } \\
(\%)\end{array}$ & 11 & 13 & 13 & - & 9 & 12 & 13 & 8 & 2 & 15 & 16 & 7 \\
\hline & $\begin{array}{c}\text { Avr } \\
(/ 10)\end{array}$ & 3.0 & 3.0 & 2.9 & 2.8 & 2.7 & 3.2 & 3.1 & 2.8 & 2.4 & 3.3 & 3.4 & 2.6 \\
\hline
\end{tabular}

According to the table, there are significant differences between the age group of 36-55 and 20-35 in terms of finding the advertisement exciting. The older age group finds the advertisement more exciting. In the same proposition, a similar situation exists between married and unmarried; married couples found the ad more exciting. It is seen that the participants in Ankara have a lower level of participation, especially in the positive propositions related to the advertisement, compared to the participants in Istanbul. It is a general inference that the older age group has higher participation in positive propositional statements among age groups. In general, advertising evoked more positive connotations in the upper age group than in the lower age group.

\section{CONCLUSION and DISCUSSION}

Advertising is also of great importance for hotel businesses; hotel advertisements play a preparatory role for potential customers to visit accommodation establishments. Businesses in the service sector need to differentiate themselves from their competitors, increase their awareness and be preferred. But advertising is an expensive process; moreover, making high-value investments in an advertisement or promotional image often does not guarantee success. The deficiencies of classical research methods due to their cult characteristics, at the point of revealing the effectiveness of advertising, the level of interest of the advertisements in the target consumer group and whether they can establish the right communication with them, paved the way for the emergence of neuromarketing as a discipline as a result of the revolutionary developments in technology combined with new searches. From this point of view, the effect of the advertisement film, which is used as a marketing and promotional tool by a hotel business, on the perception of the target audience has been tried to be revealed by using the CAPI technique.

When evaluating the results obtained using the CAPI technique; Considering the general appreciation of the advertisement, it is seen that approximately one out of every 2 people likes the advertisement very much. When we look at the T4B (top 4 box score) values, that is, the sum of the ratios of the highest four scale (10-9-8-7 points) values, it is seen that almost everyone likes the advertisement. Regardless of the sector, the fact that the T4B rate of likes is $90 \%$ indicates that the advertisement is highly liked. The advertisement promotes the hotel well and includes images about the hotel, giving the hotel's view, location, service quality, etc. It is thought to show general elements. It clearly gives the image of prestige and luxury it wants to give and conveys this image very clearly to the audience. In general, it is seen that the recall level of the advertisements in the hotel category is (25\%). Among the participants, the movie-assisted recall rate of the Merit Royal commercial was $26 \%$, the brand-assisted recall rate was $26 \%$, the category-assisted recall rate was $15 \%$, and the unaided recall rate was $15 \%$. Merit Royal advertisement's unaided-category-assisted recall rate is low (15\%) when evaluated on the basis of all participants; but this should be evaluated together with the formats of general advertisements in the sector and the concepts they embrace. The fact that 5-star hotel advertisements are based on similar concepts such as "luxury", "elite", 
"sea, beach" causes consumers not to remember the same type of advertisements or to confuse brands. The fact that the advertisement was found to be different was also in the background compared to other titles in which it was successful due to these reasons. On the other hand, in this platform created by hotel ads, recall rates should not be considered as the only component in advertising effectiveness. Components such as being perceived correctly in terms of content, clear transmission of messages, directing to the hotel should be evaluated holistically with the rate of recall due to the synergy it will create. It is seen that the advertisement highlights the issues that lead to the hotel in its perceived messages and reasons for appreciation. It is noteworthy that the reasons for liking mostly include emotional expressions based on the senses. In this respect, it is possible to say that advertising appeals to consumer emotions. It has been observed that the advertisement has achieved its purpose by inspiring the desire of accommodation in the hotel .

These data confirm Lanseng's (2016) findings that there are a significant number of studies showing that the use of sexual attraction in advertisements can be attractive and entertaining. On the other hand, according to the CAPI findings, the unaided recall level of the advertisement was found to be $15 \%$. The result that emerged at this point is compatible with Baker (1961) and Lachance et al.'s (1977) research, which stated that sexual attraction used in advertisements increases the attractiveness and admiration level of the advertisement but decreases the recall rate. However, the advertisement is generally of a nature that attracts the attention of the audience and keeps the audience's reaction awake. It has been determined that the advertisement creates a positive perception on the target consumer group.

As a result, Merit Royal advertisement is successful when it is considered on the basis of factors such as conveying the messages it wants to give to the consumer, directing them to the hotel, making the brand attractive and the advertisement being gripping. However, the fact that these factors are at a lower level in other brand customers is an important point to be considered.

\subsection{Limitations and Future Research}

As in any study, this study also has some limitations. In the study, the population and sample can be changed and increased quantitatively. The fact that the research coincided with the pandemic period caused serious difficulties in obtaining data. While more data could be accessed than in the normal period, the unexpected course of the process hindered this situation.In this respect, different results can be reached by changing the population and sample in future studies. Increasing the number of samples will also contribute to this difference.

The research was carried out in the tourism sector. High value-added contributions to the literature can be made with similar studies in the health sector, agriculture sector, pharmaceutical sector and industrial sector. In fact, the results to be obtained from the studies to be carried out in these different sectors can be compared with the research in the tourism sector, and the pros and cons can be revealed.

A quantitative method was adopted in this study. In future research, qualitative methods can be used as well as different quantitative methods. In particular, neuromarketing techniques, which have made a great impression in the field of marketing recently, can be utilized. More consistent results can be achieved with techniques such as eye tracking, eeg, pet, facial coding. And the results achieved can be demonstrated in comparison with traditional marketing techniques

\subsection{Managerial Implications}

The use of more modern techniques such as CAPI in the field of tourism can provide a significant advantage in creating applications that can create a strong competitive advantage, while providing the opportunity to have a specific and clear information about the desires and expectations of consumers in real time. The aim of marketing in the tourism context today should be to know and understand the customer, thus maximizing the harmonization of the offered product with the customer. At this point, the blending of traditional tourism marketing and modern techniques will help destination brand positioning, reaching new demands, effective price positioning, better knowing what potential visitors really want, understanding whether visitor preferences are rational and the role the brain plays in purchasing preferences and increased tourist satisfaction. It has the potential to contribute to the underlying perception of tourists' behavior to reach more realistic data on points such as their intention to revisit. Both confirmatory classical research results and primary data from experimental studies confirm this. At this point, it is essential for business professionals to take these outputs into account in the decisions they will make in their strategic marketing plans. In addition, making this achievement sustainable seems possible only with the integration of university-industry cooperation. 


\section{REFERENCES}

AHMED, S. and ASHFAQ, A. (2013). "Impact of Advertising on Consumers' Buying Behavior Through Persuasiveness, Brand Image, and Celebrity Endorsement", Global Media Journal, Vol. 6(2):149, pp. 1-9.

BARGH, J. A. (2002). "Losing Consciousness: Automatic Influences on Consumer Judg-Ment, Behavior, and Motivation”, J. Consum. Res. 29 (2), 280-285.

BAKER, C. (Ed.). (1961). "Hemingway and His Critics: An International Anthology". New York: Hill and Wang Inc.

BLTYHE, J. (2001). "Pazarlama İlkeleri”, (Çev: Y. Odabaşı). Eskişehir: Bilim Teknik Yayınevi.

BYUN, J. and JANG, S. (2015), "Effective Destination Advertising: Matching Effect between Advertising Language and Destination Type", Tourism Management, 50, 31-40.

CLASSER, R. (1972). “Planlı Pazarlama”, İstanbul: Reklam Yayınları.

COHEN, H. (2015). "Content Marketing VS NativeAdvertising”, http://heidicohen.com/contentmarketing-vsnative-advertising-chart/ (Access Date: 7 December 2021).

FATIMA, S. and LODHI, S. (2015), "Impact of Advertisement on Buying Behaviours of the consumers: Study of Cosmetic Industry in Karachi City", International Journal of Management Sciences and Business Research, ISSN (2226- 8235) Vol-4, Issue 10, pp. 125-137.

FOSTER, N. (1997), “Tuzu Kurular İçin Reklâmcılık”, (Çev. Ebru Gündem), 2. Basım, Yayınevi Yayıncılık, Istanbul.

JENKINS, F. (2000). “Advertising”, Revised by Daniel Yadin, 4. Bask1, Financial Times, Prentice Hall, Dorset Press, İngiltere.

JONES, P. (1995). “When Ads Work: Proof That Advertising Triggers Sales”, New York: Lexington Books.

KOENIGS, M. and TRANEL, D. (2007), "Prefrontal Cortex Damage Abolishes Brand-Cued Changes in Cola Preference", Soc. Cogn. Affect. Neurosci. 3 (1), 1-6.

KOTLER, P., BOWEN, J. and MAKENS, J. (2003) "Marketing For Hospitality And Tourism". New Jersey: Prentice Hall.

LACHANCE, C.C., LUBITZ, A. and CHESTNUT, R.W. (1977), "The Decorative Female Model: Sexual Stimuli and the Recognition of Advertisements", Journal of Advertising, 6/4, 11-14

LANSENG, EVEN J., (2016), "Relevant Sex Appeals in Advertising: Genderand Commitment Context Differences", Frontiers in Psychology, September, Volume 7, Article 1456

MCLUHAN, M. (2005), “The Medium is the Massage”, Ginko Press, Corte Madera.

RAI, N. (2013), "Impact of Advertising on Consumer Behaviour and Attitude with Reference to Consumer Durables”, International Journal Management Research \& Business Strategy, Vol. 2, No. 2, pp. 75-79.

RICHARDS, J. I. and CURRAN, C. M. (2002), "Oracles on Advertising: Searching for a Definition”, Journal of Advertising, Vol. 31, No. 2, pp. 63-77.

SHRUM, L.J. , LIU, M., NESPOLI, M. ve LOWREY, T. M. (2012), "Persuasion in the Market- Place: How Theories of Persuasion Apply to Marketing and Advertising”, In: Dillard, James, Shen, Lijiang (Eds.), The Persuasion Handbook. CA:Sage, Thousand Oaks.

STEEL, J. (2000), “Gerçek, Yalanlar, Reklamcılık”, İnci Berna Kalınyazgan (çev.), 1. Baskı, Ankara: MediaCat Yayınları, 2000, s. 21.

TAYFUR, G. (2010), “Reklamcılık”, 4. Baskı”, Ankara: Nobel Yayıncılık, s. 6.

TIKVEŞ, Ö. (2005), “Halkla İlişkiler ve Reklamcılık”, Genişletilmiş 2. Baskı, İstanbul: Beta Yayıncılık.

UZKURT, C. ve BÖLÜKBAŞI, B. (2008), "Marka Yayma Stratejisini Etkileyen Tüketici İlişkili Faktörlerin Tüketicilerin Satın Alma Niyetleri Üzerine Etkisi: Ampirik Bir Çalışma”, Hacettepe Üniversitesi İktisadi ve İdari Bilimler Fakültesi Dergisi, 26 (2), 275-305.

VENTURA, K. (2003), “Pazarlama Araştırmaları Kapsamında Yaşanan Teknoloji-Tabanlı Değişim”, Ege Akademik Bakış Dergisi, Vol 3, Is 1-2, pp. 85-86. 